\title{
ANALISIS POTENSI DAERAH (MAKRO EKONOMI) TERHADAP KELAYAKAN PENDIRIAN PT. BPR ARTA WARINGIN JAYA SITUBONDO DI WILAYAH KABUPATEN BANYUWANGI
}

\author{
Suprihadi \\ Sekolah Tinggi IImu Ekonomi Widya Dharma Malang
}

\section{INFO ARTIKEL}

\section{DOI: 10.32812/jibeka.v13i2.102}

ISSN-P: 0126-1258

ISSN-E: 2620-875X

Keywords: Regional Potential, Business Feasibility Study and $B P R$

\section{ABSTRACT}

This study aims to analyze the feasibility of PT. BPR Arta Waringin Jaya by focusing on the potential of the region (Macroeconomics). researchers use this type of research using the descriptive qualitative research method. This research focuses on aspects of community interest, the level of competition of financial institutions, potential savings, potential new loans and target markets in channeling and raising funds. The analytical method used is the data quality test and reliability test with the results of research that there are several correlation values greater than the cut off value of 0.3 with the meaning of valid and reliable data and analysis of the results of the study shows that market research has been done for public interest in BPR as measured by the existence of BPR in Banyuwangi, services provided, professionalism of services, offering attractive products and ease of access to banking services can be concluded that the public interest responds very positively to the existence of PT BPR Artha Waringin Situbondo. So that the community will accept if there are banking activities in the area to provide banking services.
Kata Kunci: Potensi Daerah, Studi Kelayakan Usaha dan BPR

\section{ABSTRAK}

Penelitian ini bertujuan untuk menganalisis sebuah kelayakan PT.BPR Arta Waringin Jaya dengan memfokuskan pada aspe potensi daerah (Makro Ekonomi). peneliti menggunakan jenis penelitian dengan menggunakan metode Penelitian Deskriptif Kualitatif. Penelitian ini fokus pada aspek minat masyarakat, tingkat persaingan lembaga keuangan, potensi tabungan, potensi kredit baru dan target pasar dalam penyaluran dan penghimpunan dana. Metode analisa yang digunakan adalah uji kualitas data dan uji reliabilitas dengan hasil penelitian bahwa terdapat beberapa nilai korelasi lebih besar dari nilai cut off sebesar 0.3 dengan artian data bersifat valid dan reliabel dan analisis dari hasil penelitian menunjukkan bahwa penelitian pasar yang telah dilakukan untuk minat masyarakat terhadap BPR yang diukur dari keberadaan BPR di Banyuwangi, pelayanan yang diberikan, profesionalitas layanan, menawarkan produk yang menarik serta kemudahan dalam akses pelayanan perbankan dapat disimpulkan bahwa minat masyarakat merespons sangat positif terhadap keberadaan PT BPR Artha Waringin Situbondo. Sehingga masyarakat akan menerima bila ada aktivitas perbankan di daerah tersebut untuk memberikan pelayanan perbankan. 


\section{Pendahuluan}

Perubahan kebijakan pemerintah pusat di dalam pengelolaan kepemerintahan dari sentralisasi menjadi desentralisasi, ternyata membawa dampak yang cukup positif bagi proses menuju kemandirian daerah, termasuk Kabupaten Banyuwangi. Kehadiran UU No. 22 Tahun 1999 tentang Otonomi Daerah dan UU No. 25 Tahun 1999 tentang Perimbangan Keuangan antara Pemerintah Pusat dan Pemerintah Daerah merupakan suatu upaya, kesempatan dan dukungan bagi daerah untuk mandiri. Pendayagunaan potensi sumber daya yang ada perlu dilakukan dengan mengutamakan sebesar-besarnya untuk kemakmuran ekonomi masyarakat sebagai refleksi pencapaian suatu pembangunan ekonomi yang berkelanjutan. Oleh karena itu diperlukan upaya pendayagunaan sumber daya yang efektif, efisien dan berkelanjutan.

Salah satu faktor utama dalam peningkatan taraf hidup suatu masyarakat tidak lain adalah tingkat perekonomian masyarakat itu sendiri dengan mendayagunakan atau memaksimalkan potensi yang ada. Banyuwangi merupakan daerah dengan potensi yang sangat besar untuk dapat di dikelalo baik potensi dari alamnya maupun potensi dari sumberdaya manusianya dengan kata lain dari segi modal masyarakat banyuwangi sudah berada pada ambang batas masyarakat dengan perekonomian yang baik. Sektor pariwisata yanga ada dibanyuwangi misalnya akhir-akhir ini sudah banyak yang di ekpos menjadi pintu destinasi wisata sebelum berkunjung ke Bali. Dengan di ekposnya berbagai obyek pariwisata oleh pemerintah Banyuwangi ini lah secara tidak langsung membuka lapangan pekerjaan bagi masyarakat banyuwangi sendiri.

Keberhasilan dalam peningkatan pendapatan (ekonomi) suatu daerah akan dipengaruhi oleh kegiatan usaha yang bisa dikembangkan dan permodalan yang dapat disediakan serta kondisi pasar yang mendukungnya. Sedangkan kegiatan usaha itu sendiri keberhasilannya akan dipengaruhi oleh kondisi sumber alam yang ada, teknologi yang tersedia serta kualitas SDM yang akan mengelolanya. Penguatan ekonomi sebagai refleksi otonomi daerah di dalam pembangunan wilayah Kabupaten telah diterapkan secara penuh, maka secara langsung Pemerintah Kabupaten memiliki kewenangan yang lebih leluasa untuk pelaksanaan pembangunan antara lain dengan penguatan lembaga keuangan daerah dalam bentuk perbankan yang dilaksanakan secara efektif dan efisien dan diatur dalam UU No. 7 Tahun 1992 tentang Perbankan juncto UU No. 10 Tahun 1998 tentang Perubahan atas UU No. 7 tahun 1992 tentang perbankan yang dalam pelaksanaannya diatur dengan (a) PP No. 70 Tahun 1992 tentang Bank Umum, (b) PP No. 71 Tahun 1992 tentang Bank Perkreditan Rakyat dan (c) PP No. 72 Tahun 1992 tentang Bank Bagi Hasil (Bank Syariah).

Bank pada dasarnya merupakan lembaga perantara yang menghimpun dana dari masyarakat kelebihan dana dan menyalurkannya kepada masyarakat kekurangan dana dalam bentuk pembiayaan/kredit yang diberikan maupun penempatan dana lainnya. Selain menghimpun dana dan menyalurkan dana, bank dalam pelaksanaan tugasnya berfungsi sebagai urat nadi perekonomian bangsa. Dukungan perbankan terhadap pertumbuhan perekonomian nasional memang sangat besar, baik dalam mendorong pertumbuhan sektor riil maupun dalam menciptakan kelancaran serta kenyamanan dalam bertransaksi. Disamping itu, seiring dengan perkembangan ilmu pengetahuan dan teknologi, perbankan senantiasa berinovasi dan menciptakan berbagai produk perbankan yang sangat dibutuhkan oleh masyarakat. Sehingga berbagai layanan dan kemudahan transaksi melalui perbankan terus ditingkatkan. 
Sejalan dengan perkembangan tersebut keberadaan lembaga perbankan sangatlah diperlukan dan diharapkan dapat lebih memacu perkembangan ekonomi masyarakat terutama pada sektor permodalan bagi UMKM. Hal inilah mendorong manajemen PT. BPR Artha Waringin Jaya - Situbondo untuk membuka kantor cabang di Kecamatan Banyuwangi wilayah Kabupaten Banyuwangi. Keberadaan Kantor Cabang PT BPR Artha Waringin Jaya Situbondo tersebut diharapkan berfungsi sebagai penunjang bagi pertumbuhan ekonomi dan meningkatkan kesejahteraan masyarakat.

Berkaitan dengan studi kelayakan yang harus dibuat, didalamnya harus diketahui respektasi dari kondisi masyarakat yang akan dijadikan sebagai obyek perusahaan yaitu preferensi masyarakat di kabupaten Banyuwangi terhadap keberadaan Kantor Cabang BPR nantinya. Untuk itu perlu dilakukan survey masyarakat untuk meneliti sejauh mana preferensi tersebut serta dinamika masyarakat terhadap rencana pendirian kantor cabang BPR baru.

\section{Metode Penelitian}

Perubahan kebijakan pemerintah pusat di dalam pengelolaan kepemerintahan dari sentralisasi menjadi desentralisasi, ternyata membawa dampak yang cukup positif bagi proses menuju kemandirian daerah, termasuk Kabupaten Banyuwangi. Kehadiran UU No. 22 Tahun 1999 tentang Otonomi Daerah dan UU No. 25 Tahun 1999 tentang Perimbangan Keuangan antara Pemerintah Pusat dan Pemerintah Daerah merupakan suatu upaya, kesempatan dan dukungan bagi daerah untuk mandiri. Pendayagunaan potensi sumber daya yang ada perlu dilakukan dengan mengutamakan sebesar-besarnya untuk kemakmuran ekonomi masyarakat sebagai refleksi pencapaian suatu pembangunan ekonomi yang berkelanjutan. Oleh karena itu diperlukan upaya pendayagunaan sumber daya yang efektif, efisien dan berkelanjutan.

Salah satu faktor utama dalam peningkatan taraf hidup suatu masyarakat tidak lain adalah tingkat perekonomian masyarakat itu sendiri dengan mendayagunakan atau memaksimalkan potensi yang ada. Banyuwangi merupakan daerah dengan potensi yang sangat besar untuk dapat di dikelalo baik potensi dari alamnya maupun potensi dari sumberdaya manusianya dengan kata lain dari segi modal masyarakat banyuwangi sudah berada pada ambang batas masyarakat dengan perekonomian yang baik. Sektor pariwisata yanga ada dibanyuwangi misalnya akhir-akhir ini sudah banyak yang di ekpos menjadi pintu destinasi wisata sebelum berkunjung ke Bali. Dengan di ekposnya berbagai obyek pariwisata oleh pemerintah Banyuwangi ini lah secara tidak langsung membuka lapangan pekerjaan bagi masyarakat banyuwangi sendiri.

Keberhasilan dalam peningkatan pendapatan (ekonomi) suatu daerah akan dipengaruhi oleh kegiatan usaha yang bisa dikembangkan dan permodalan yang dapat disediakan serta kondisi pasar yang mendukungnya. Sedangkan kegiatan usaha itu sendiri keberhasilannya akan dipengaruhi oleh kondisi sumber alam yang ada, teknologi yang tersedia serta kualitas SDM yang akan mengelolanya. Penguatan ekonomi sebagai refleksi otonomi daerah di dalam pembangunan wilayah Kabupaten telah diterapkan secara penuh, maka secara langsung Pemerintah Kabupaten memiliki kewenangan yang lebih leluasa untuk pelaksanaan pembangunan antara lain dengan penguatan lembaga keuangan daerah dalam bentuk perbankan yang dilaksanakan secara efektif dan efisien dan diatur dalam UU No. 7 Tahun 1992 tentang Perbankan juncto UU No. 10 Tahun 1998 tentang Perubahan atas UU No. 7 tahun 1992 tentang perbankan yang dalam pelaksanaannya diatur dengan (a) 
PP No. 70 Tahun 1992 tentang Bank Umum, (b) PP No. 71 Tahun 1992 tentang Bank Perkreditan Rakyat dan (c) PP No. 72 Tahun 1992 tentang Bank Bagi Hasil (Bank Syariah).

Bank pada dasarnya merupakan lembaga perantara yang menghimpun dana dari masyarakat kelebihan dana dan menyalurkannya kepada masyarakat kekurangan dana dalam bentuk pembiayaan/kredit yang diberikan maupun penempatan dana lainnya. Selain menghimpun dana dan menyalurkan dana, bank dalam pelaksanaan tugasnya berfungsi sebagai urat nadi perekonomian bangsa. Dukungan perbankan terhadap pertumbuhan perekonomian nasional memang sangat besar, baik dalam mendorong pertumbuhan sektor riil maupun dalam menciptakan kelancaran serta kenyamanan dalam bertransaksi. Disamping itu, seiring dengan perkembangan ilmu pengetahuan dan teknologi, perbankan senantiasa berinovasi dan menciptakan berbagai produk perbankan yang sangat dibutuhkan oleh masyarakat. Sehingga berbagai layanan dan kemudahan transaksi melalui perbankan terus ditingkatkan.

Sejalan dengan perkembangan tersebut keberadaan lembaga perbankan sangatlah diperlukan dan diharapkan dapat lebih memacu perkembangan ekonomi masyarakat terutama pada sektor permodalan bagi UMKM. Hal inilah mendorong manajemen PT. BPR Artha Waringin Jaya - Situbondo untuk membuka kantor cabang di Kecamatan Banyuwangi wilayah Kabupaten Banyuwangi. Keberadaan Kantor Cabang PT BPR Artha Waringin Jaya Situbondo tersebut diharapkan berfungsi sebagai penunjang bagi pertumbuhan ekonomi dan meningkatkan kesejahteraan masyarakat.

Berkaitan dengan studi kelayakan yang harus dibuat, didalamnya harus diketahui respektasi dari kondisi masyarakat yang akan dijadikan sebagai obyek perusahaan yaitu preferensi masyarakat di kabupaten Banyuwangi terhadap keberadaan Kantor Cabang BPR nantinya. Untuk itu perlu dilakukan survey masyarakat untuk meneliti sejauh mana preferensi tersebut serta dinamika masyarakat terhadap rencana pendirian kantor cabang BPR baru.

\section{Hasil Penelitian dan Pembahasan}

\section{Potensi Ekonomi Makro}

Perkembangan di Kabupaten Banyuwangi dalam kurun 5 (lima) tahun terakhir mengalami fluktuasi pertumbuhan yang relatif stabil dan positif. Hal ini bisa dianalisa dari pertumbuhan dan perkembangan dari Produk Domestik Regional Bruto (PDRB) berdasarkan harga konstan tahun dasar 2010 dengan 17 bidang usaha/sektor di Kabupaten Banyuwangi. Untuk pembahasan sektor makro ekonomi Kabupaten Banyuwangi pada sektor PDRB, data yang dapat disajikan adalah pada tahun 2013 - 2017 untuk harga konstan (2010) serta dengan proyeksi tahun 2018 sampai tahun 2020.

\section{PDRB Berdasarkan Harga Konstan}

Pembangunan ekonomi Kabupaten Banyuwangi mulai tahun 2013 sampai dengan 2017 terus mengalami kemajuan, hal ini tercermin dari meningkatnya total PDRB harga konstan tahun dasar 2010 setiap tahunnya, dengan pertumbuhan yang cenderung meningkat. Hal ini menunjukkan bahwa kenaikan PDRB dari tahun 2013 hingga 2017 tidak hanya diakibatkan oleh kenaikan harga saja, tetapi juga dikarenakan adanya peningkatan kapasitas produksi daerah Kabupaten Banyuwangi 
Grafik 1. Pertumbuhan PDRB (\%) Kabupaten Banyuwangi Tahun 2013-2017 dan Hasil Proyeksi Tahun 2018-2020

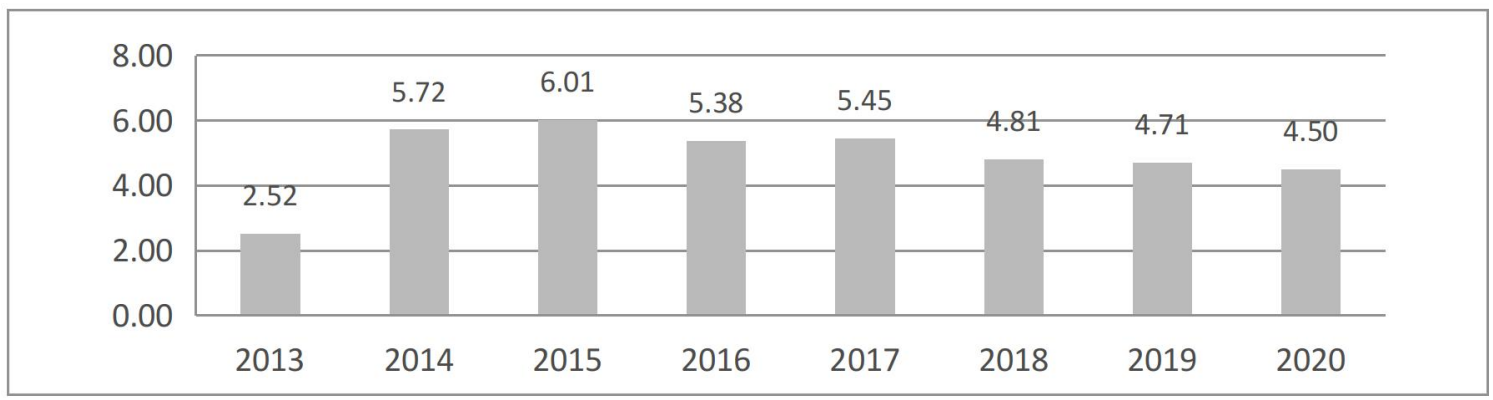

Perkembangan dan pertumbuhan ekonomi Kabupaten Banyuwangi pada dasarnya didominasi oleh tiga sektor utama yang mampu menyumbangkan kontribusi terbesar dari PDRB diatas 10\%. Untuk tahun 2017 sektor-sektor tersebut adalah Sektor Pertanian Kehutanan dan Perikanan sebesar 31,55\%, kemudian Perdagangan Besar dan Eceran: Reparasi Mobil dan Sepeda Motor sebesar 15,09\% serta sektor Konstruksi sebesar $11,71 \%$. Pada perkembangan trend untuk berbagai sektor potensial, sektor pertanian terus mengalami trend penurunan, tetapi trend perdagangan cenderung mengalami kenaikan.

Secara garis besar bisa disimpulkan bahwa kondisi perekonomian pada lima tahun terakhir menunjukkan perkembangan yang positif dengan trend yang bagus pula sehingga diperkirakan tiga tahun mendatang kondisi perekonomian di kabupaten Banyuwangi akan terus bergerak dan tumbuh dengan stabilitas yang baik meskipun tekanan ekonomi masih terus terjadi.

Pertumbuhan ekonomi di samping dapat berdampak pada peningkatan pendapatan, pada akhirnya juga akan berpengaruh pada pendapatan daerah. Semakin mampu menggali potensi perekonomian daerah yang ada, maka akan semakin besar PDRB dan Pendapatan Asli Daerah, sehingga mampu meningkatkan keuangan daerah dalam menunjang pelaksanaan otonomi daerah.

\section{Jumlah Penduduk}

Jumlah penduduk Kabupaten Banyuwangi menurut BPS Kabupaten Banyuwangi tahun 2017 tercatat 1.609 .983 yang terdiri dari 798.926 orang penduduk laki-laki atau $49,62 \%$ dan 805.971 orang penduduk perempuan atau 50,38\%. Dibandingkan dengan tahun 2016, jumlah penduduk menunjukkan kenaikan sekitar $0,32 \%$.

Sedangkan, berdasarkan komposisi pertumbuhan jumlah penduduk dari tahun 2013 sampai dengan tahun 2017 pertumbuhan penduduk rata-rata setiap tahun positif 0,45\%, sedangkan untuk angka proyeksi selama tiga tahun (tahun 2018-tahun 2020) rata-rata pertumbuhan penduduk diperkirakan setiap tahun tumbuh positif sebesar $0,32 \%$. Hal ini terlihat pada grafik 2 .

Grafik 2. Perkembangan Jumlah Penduduk Kabupaten Banyuwangi Tahun 2013-2017 dan Proyeksi tahun 2018-2020 


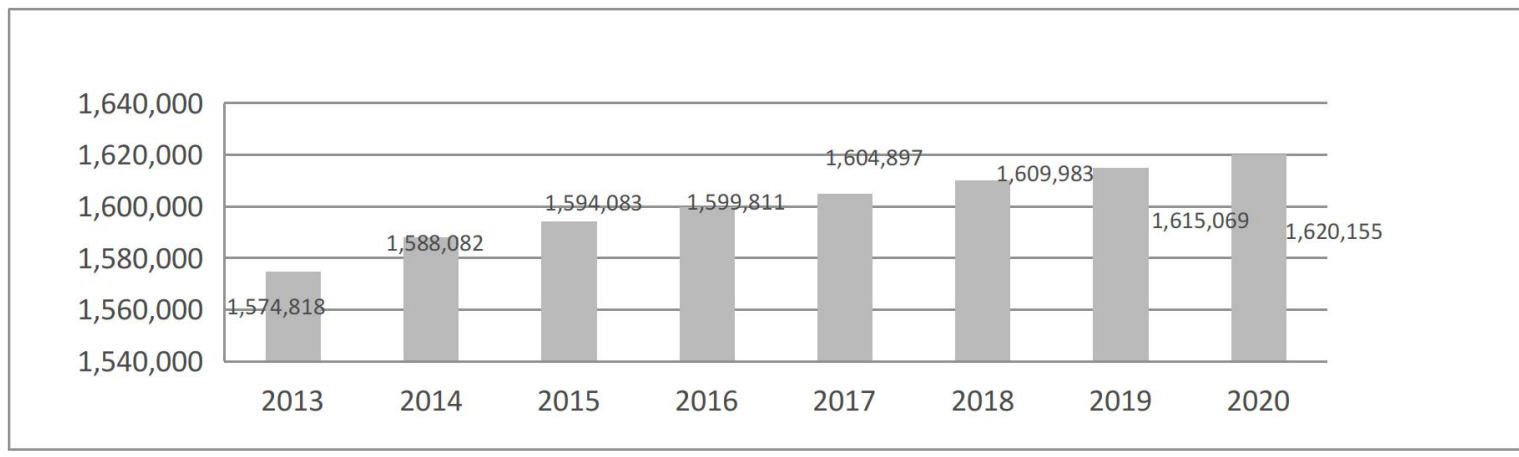

Secara spesifik Kecamatan Banyuwangi (lokasi Kantor Cabang PD BPR Bank Banyuwangi) pada akhir tahun 2017 jumlah penduduknya 110.042 jiwa tumbuh positif $0,35 \%$ dibanding dengan tahun sebelumnya. Sedangkan angka proyeksi untuk tahun 2020 diperkirakan jumlah penduduk kecamatan Banyuwangi berjumlah 111.922 Jiwa.

\section{Pendapatan Per Kapita}

Perkembangan dan pertumbuhan jumlah penduduk di kabupaten Banyuwangi mampu diimbangi dengan kemampuan daya beli masyarakat yang semakin baik, hal ini ditunjukkan dengan besarnya pendapatan per kapita masyarakat lima tahun terakhir tumbuh dengan baik dan proyeksi lima tahun menunjukkan trend yang meningkat pula.

Dimana pertumbuhan pendapatan per kapita mulai tahun 2013-2017 tumbuh ratarata per tahun $9,11 \%$ serta pada proyeksi dari tahun 2018-2020 menunjukkan pertumbuhan rata-rata per tahun adalah $6,38 \%$. Sedangkan bila diukur pertumbuhan dari tahu 2013-2020 rata-rata pertumbuhan pertahun sebesar 7,9\%. Hal ini menunjukkan bahwa tingkat kesejahteraan masyarakat kabupaten Banyuwangi terus mengalami peningkatan dan perbaikan setiap tahunnya. Hal ini terlihat pada grafik 3 .

Grafik 3. Pendapatan Per-Kapita (Juta Rupiah) Kabupaten Banyuwangi Tahun 2013-2017 dan hasil Proyeksi Tahun 2018-2020

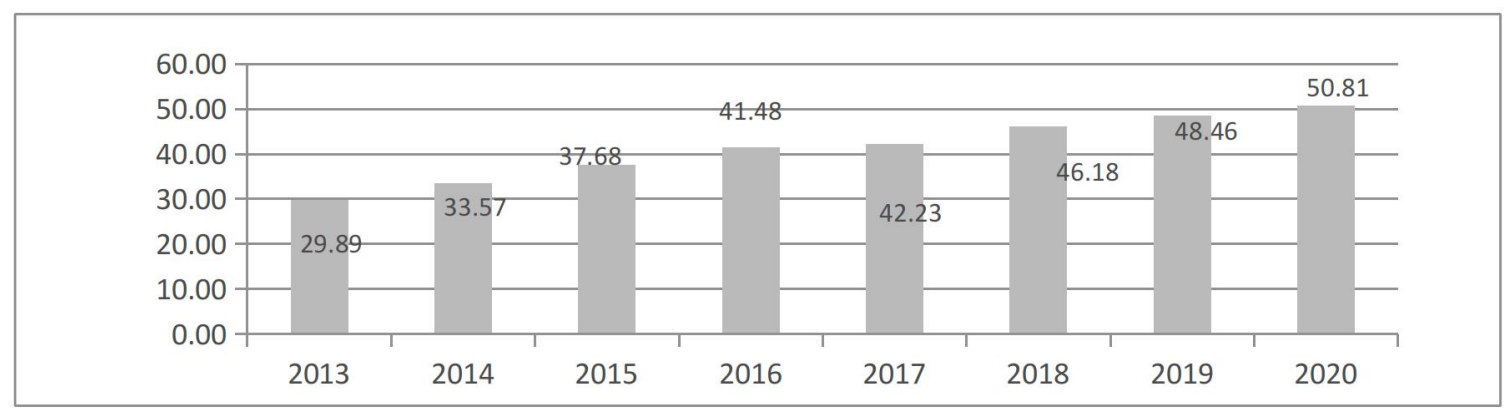

\section{Tingkat Inflasi}

Kenaikan indeks harga secara agregat di kabupaten Banyuwangi setiap tahun yang moderat menunjukkan nilai peningkatan kualitas hidup yang diukur dari kemampuan daya beli masyarakat serta kenaikan indeks harga mampu tumbuh secara liniaer. Hal ini menunjukkan adanya stimulator pertumbuhan ekonomi masyarakat, dimana adanya peningkatan kualitas kesejahteraan dengan kemampuan daya beli masyarakat yang baik 
serta adanya nilai barang dan jasa yang meningkat pula tetapi masyarakat mampu memenuhinya. Hal ini ditunjukkan oleh grafik 4.

Grafik 4. Tingkat Inflasi (persen) Kabupaten Banyuwangi Tahun 2013-2017 dan hasil Proyeksi tahun 20182020

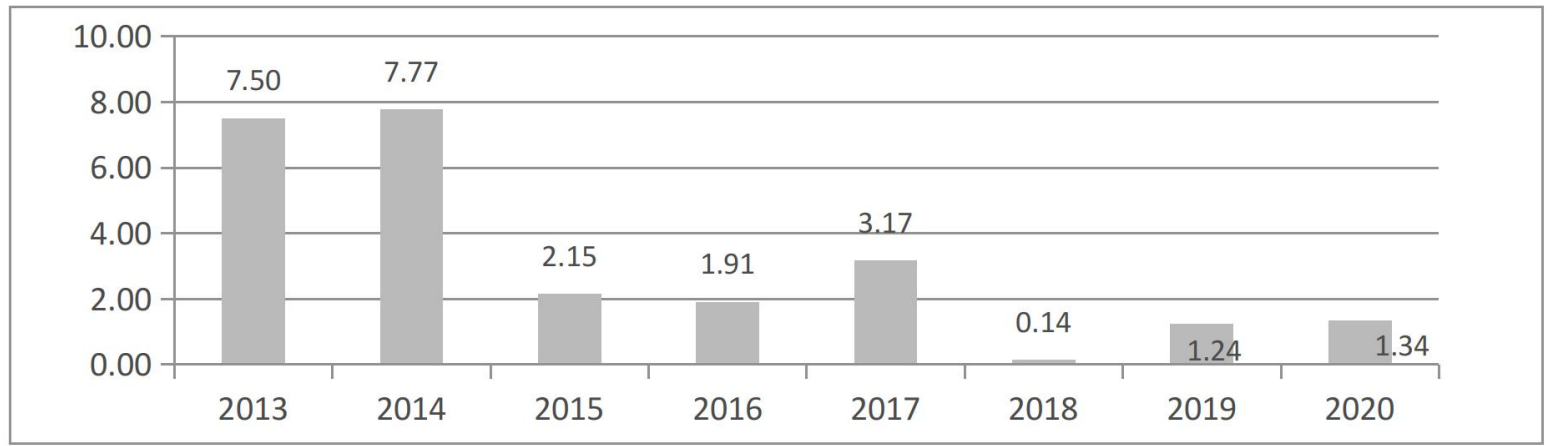

\section{Jumlah UMKM}

Pertumbuhan UMKM di Kabupaten Banyuwangi dari empat sektor pembangunan yang terus meningkat adalah sektor industri pengolahan, sektor perdagangan serta sektor hotel dan restoran. Hal ini mencerminkan tumbuh dan berkembangnya aktivitas masyarakat dalam membangun potensi ekonomi melalui kegiatan usaha produktif. Dari kegiatan industri yang berkembang baik di sektor formal maupun non formal dan berkembangnya sektor perdagangan baik barang maupun jasa menunjukkan terus meningkatnya pelaku-pelaku bisnis dari Usaha Mikro Kecil menengah (UMKM) di kabupaten Banyuwangi. Hal ini tercermin dari trend pertumbuhan pelaku bisnis sejak tahun 2013-2017 yang berkembang rata-rata 7,81\% per tahun dan diproyeksikan tahun 2018-2020 rata-rata pertahun pertumbuhannya sebesar 5,61\%. Bila dihitung secara kontinyu dari tahun 2013-2020 rata-rata pertumbuhan jumlah UMKM setiap tahunnya sebesar $6,87 \%$. Hal ini mencerminkan akan terus berkembangnya sektor UMKM seiiring dengan membaiknya kondisi perekonomian nasional dewasa ini. Hal ini menunjukkan potensi UMKM akan menjadi pilar bagi pertumbuhan dan perkembangan ekonomi di wilayah kabupaten Banyuwangi. Hal ini ditunjukkan pada grafik 5.

Grafik 5. Jumlah UMKM Kabupaten Banyuwangi Tahun 2013-2017 dan Hasil Proyeksi Tahun 2018-2020

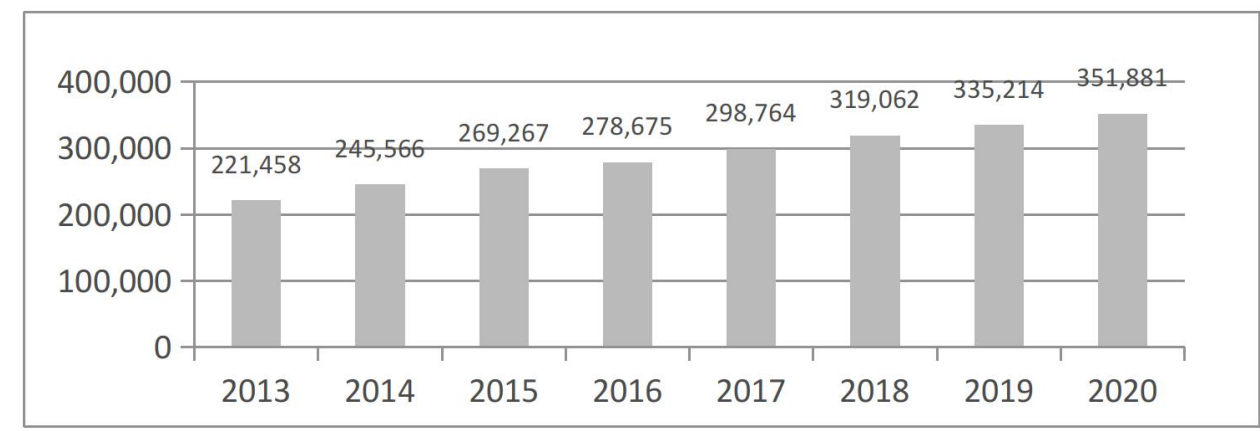




\section{Jumlah Pasar (Tradisional)}

Dengan perkembangan sektor perdagangan di wilayah kabupaten Banyuwangi yang terus meningkat serta kontribusinya terhadap Produk Domestik Regional Bruto dari tahun ke tahun terus meningkat salah satunya ditopang banyak pasar tradisional yang tersedia di wilayah kabupaten Banyuwangi. Kondisi pasar di Banyuwangi untuk jenis pasar umum maupun pasar khusus relatif tetap namun ada bebrapa penambahan pada tahun 214 dari 109 buah menjadi 111 jumlahnya dan bila dilihat dari aktifiasnya pasar tradisionalumum semakin ramai dengan banyaknya pedagang yang berjualan.

Namun kalau dilihat dari pasar yang cakupannya lebih kecil (contoh pasar desa atau pasar krempyeng) jumlahnya banyak dan terus tumbuh di wilayah kabupaten Banyuwangi. Data terkait pasar tradisional/umum di Banyuwangi yang dapat disajikan sebagaimanai ditunjukkan pada Grafik 6 dibawah ini.

Grafik 6. Jumlah Pasar Tradisional/Umum di Kabupaten Banyuwangi Tahun 2013-2020

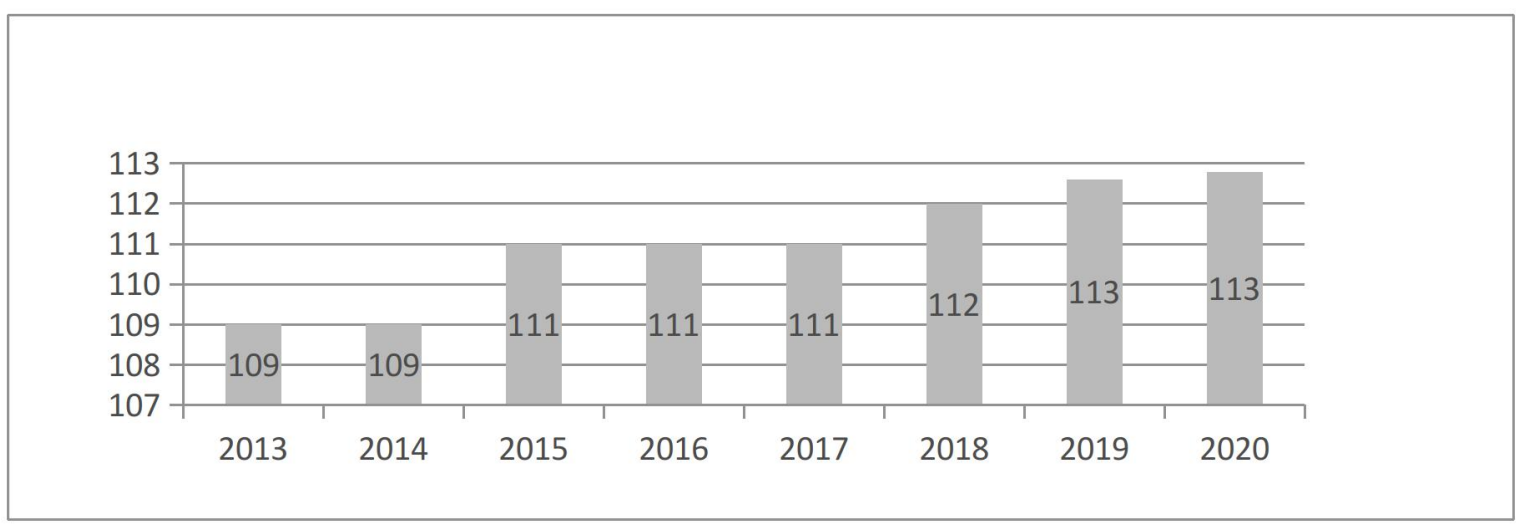

Disimpulkan dari analisis trend perkembangan pasar tradisional/umum di kabupaten Banyuwangi akan selalu stabil untuk tiga tahun mendatang. Dengan demikian pelaku usaha akan bisa terus berkembang sehingga produktifitas masyarakat Banyuwangi juga akan bisa ditingkatkan sehingga mampu menggerakkan pertumbuhan perekonomian di wilayah kabupaten Banyuwangi.

\section{Upah Minimum Regional}

Peningkatan kualitas kesejahteraan masyaraakat di Banyuwangi slah satu indikatornya adalah meningkatnya pendapatan perkapita dan kemampuan daya beli masyaraakat untuk memenuhi kebutuhan dan keinginannya. Daya beli masyarakat tersebut tercermin dari peningkatan jumlah Upah Minimum Regional di wilayah Banyuwangi. Sejak tahun 2013 sampai tahun 2017 UMR di kabupaten Banyuwangi meningkat rata-rata $14,56 \%$ pertahun. Dengan kondisi perekonomian kedepan diproyeksikan UMR juga akan mengalami kenaikan yang signifikan pula sebesar $8,47 \%$. Hal ini terlihat pada grafik 7 .

Grafik 7. Nilai Upah Minimum Regional (UMR) Kabupaten Banyuwangi Tahun 2013-2017 dan hasil proyeksi tahun 2018-2020 


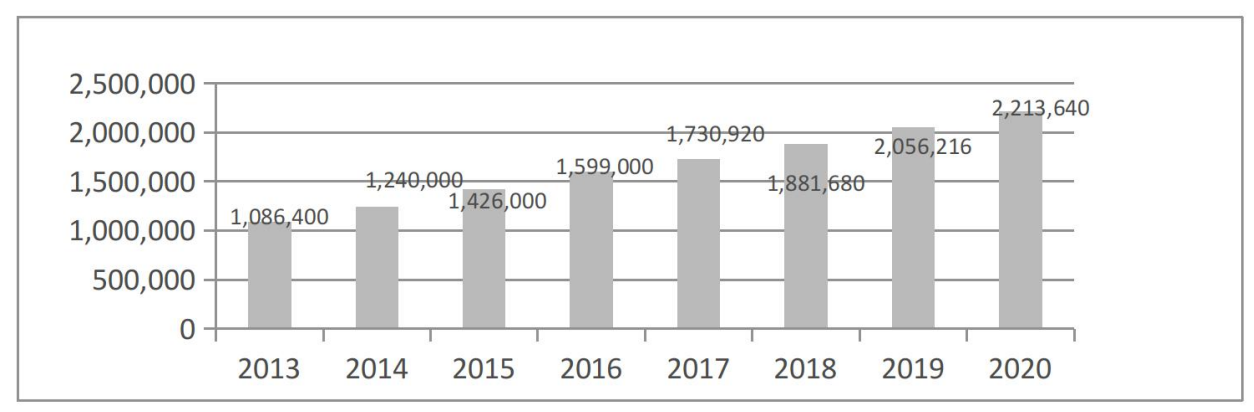

Dengan terjadinya peningkatan UMR maka menunjukkan geliat kapasitas produksi di Banyuwangi terus mengalami peningkatan baik dari sisi kualitas produksi maupun dari sisi kuantitas produksi. Sehingga sektor-sektor pembangunan yang ada mampu menopang terjadinya kenaikan kualitas kesejahteraan masyarakat yang diukur dari peningkatan UMR di Kabupaten Banyuwangi.

\section{Hasil Penelitian dan Pembahasan}

Dalam melakukan penelitian ini, peneliti menggunakan jenis metode penelitian kuantitatif-kualitatif dengan menggunakan program SPSS Setelah itu hasil dideskripsikan sesuai dengan hasil output analisis (penelitian kualitatif).

Lokasi penelitian yang dilakukan oleh peneliti di wilayah kabupaten Banyuwangi dengan mengambil Populasi dan Sampel sebanyak 60 pada dua kecamatan yaitu: kecamatan Banyuwangi, Kecamatan Genteng pada bulan Juli-Agustusi tahun 2018 dengan teknis menyebarkan kuisioner penelitian. Adapun hasil uji validitas sebagai berikut : Perhitungan dilakukan dengan mengkorelasikan setiap skor item dengan skor total dengan menggunakan teknik Korelasi Pearson. Hal ini terlihat di Tabel 1 dan Tabel 2.

Tabel 1. Hasil Analisis Uji Validitas

\begin{tabular}{|c|c|c|c|c|}
\hline Variabel & Item & $\begin{array}{l}\text { Koefisien } \\
\text { Validitas }\end{array}$ & Cut Off & Keterangan \\
\hline \multirow{5}{*}{$\begin{array}{l}\text { 1. Minat Masyarakat Terhadap } \\
\text { BPR }\end{array}$} & $\mathrm{X} 1.1$ & 0.744 & 0.3 & Valid \\
\hline & X1.2 & 0.784 & 0.3 & Valid \\
\hline & $\times 1.3$ & 0.754 & 0.3 & Valid \\
\hline & $\times 1.4$ & 0.777 & 0.3 & Valid \\
\hline & X1.5 & 0.695 & 0.3 & Valid \\
\hline \multirow{5}{*}{$\begin{array}{l}\text { 2. Tingkat Persaingan } \\
\text { Lembaga Keuangan Bank } \\
\text { Dan Lembaga Keuangan } \\
\text { Bukan Bank }\end{array}$} & $\mathrm{X} 2.1$ & 0.677 & 0.3 & Valid \\
\hline & $\mathrm{X} 2.2$ & 0.765 & 0.3 & Valid \\
\hline & $\times 2.3$ & 0.692 & 0.3 & Valid \\
\hline & $\mathrm{X} 2.4$ & 0.766 & 0.3 & Valid \\
\hline & $\times 2.5$ & 0.643 & 0.3 & Valid \\
\hline \multirow{5}{*}{$\begin{array}{l}\text { 3. Potensi Tabungan dan } \\
\text { Deposito BPR Baru }\end{array}$} & X3.1 & 0.745 & 0.3 & Valid \\
\hline & X3.2 & 0.764 & 0.3 & Valid \\
\hline & X3.3 & 0.743 & 0.3 & Valid \\
\hline & X3.4 & 0.764 & 0.3 & Valid \\
\hline & X3.5 & 0.771 & 0.3 & Valid \\
\hline
\end{tabular}




\begin{tabular}{|l|c|c|c|c|}
\hline \multirow{4}{*}{ 4. Potensi Kredit BPR Baru } & X4.1 & 0.681 & 0.3 & Valid \\
\cline { 2 - 5 } & $\mathrm{X} 4.2$ & 0.789 & 0.3 & Valid \\
\cline { 2 - 5 } & $\mathrm{X} 4.3$ & 0.763 & 0.3 & Valid \\
\cline { 2 - 5 } & $\mathrm{X} 4.4$ & 0.778 & 0.3 & Valid \\
\cline { 2 - 5 } & $\mathrm{X} 4.5$ & 0.687 & 0.3 & Valid \\
\hline \multirow{4}{*}{$\begin{array}{l}\text { 5. Target Pasar Penyaluran } \\
\text { Kredit dan Penghimpunan } \\
\text { Dana }\end{array}$} & $\mathrm{X} 5.1$ & 0.681 & 0.3 & Valid \\
\cline { 2 - 5 } & $\mathrm{X} 5.2$ & 0.712 & 0.3 & Valid \\
\cline { 2 - 5 } & $\mathrm{X} 5.3$ & 0.676 & 0.3 & Valid \\
\cline { 2 - 5 } & $\mathrm{X} 5.4$ & 0.682 & 0.3 & Valid \\
\cline { 2 - 5 } & $\mathrm{X} 5.5$ & 0.732 & 0.3 & Valid \\
\hline
\end{tabular}

Berdasarkan hasil pengujian validitas instrumen bahwa terdapat beberapa nilai korelasi lebih besar dari nilai cut off sebesar 0.3. Dengan demikian item-item pertanyaan di variabel tersebut dinyatakan valid dan dapat dipergunakan sebagai alat pengumpul data dalam penelitian ini.

Adapun rangkuman interpretasi reliabilitas kuisioner sesuai dengan Output SPSS dapat dilihat pada Tabel 1.

Tabel 2. Hasil Uji Reliabilitas

\begin{tabular}{|l|c|c|c|}
\hline \multicolumn{1}{|c|}{ Variabel } & $\begin{array}{c}\text { Koefisien } \\
\text { Reliabilitas }\end{array}$ & Cut Off & Keterangan \\
\hline 1. Minat Masyarakat Terhadap BPR & 0.778 & 0.6 & Reliabel \\
\hline $\begin{array}{l}\text { 2. Tingkat Persaingan Lembaga Keuangan } \\
\text { Bank Dan Lembaga Keuangan Bukan } \\
\text { Bank }\end{array}$ & 0.783 & 0.6 & Reliabel \\
\hline 3. Potensi Tabungan dan Deposito BPR Baru & 0.726 & 0.6 & Reliabel \\
\hline 4. Potensi Kredit BPR Baru & 0.789 & 0.6 & Reliabel \\
\hline $\begin{array}{l}\text { 5. Target Pasar Penyaluran Kredit dan } \\
\text { Penghimpunan Dana }\end{array}$ & 0.772 & 0.6 & Reliabel \\
\hline
\end{tabular}

Berdasarkan Tabel 2. tersebut, diketahui bahwa nilai semua variabel mempunyai Alpha Cronbach yang lebih besar dari 0.6, sehingga variabel tersebut dinyatakan handal dan layak dipergunakan sebagai alat pengumpul data.

Identitas responden digunakan untuk mengetahui karakteristik dari responden yang telah berpartisipasi dalam penelitian ini. Karakteristik tersebut dapat ditinjau dari enam hal, yaitu jenis kelamin, pekerjaan, dan pendidikan terakhir, jumlah keluarga, status kepemilikan tempat tinggal dan pendapatan setiap bulan. Adapun kesimpulan Hasil survey Pasar adalah sebagai berikut :

a. Identitas Responden

Identitas responden yang merupakan karakteristik responden menjelaskan jenis kelamin responden, pekerjaan responden, pendidikan terakhir responden, jumlah keluarga dan pendapatn setiap bulan. Adapun karakteristik responden sebagaimana terlihat pada Tabel 3.

Tabel 3. Tabel Karakteristik Responden 


\begin{tabular}{|c|c|c|c|}
\hline No. & Identitas Responden & Jumlah & Prosentase \\
\hline \multirow{3}{*}{1} & Jenis kelamin & & \\
\hline & $\Leftrightarrow$ Pria & 59 & 59 \\
\hline & Wanita & 41 & 41 \\
\hline \multirow{7}{*}{2} & Pekerjaan & & \\
\hline & PNS & 7 & 7 \\
\hline & $\oplus$ Pegawai Swasta & 6 & 6 \\
\hline & $\oplus$ Petani & 38 & 38 \\
\hline & $\oplus$ Wiraswasta & 36 & 36 \\
\hline & $\ominus \mathrm{TNI} / \mathrm{POLRI}$ & 3 & 3 \\
\hline & Lainnya & 10 & 10 \\
\hline \multirow{6}{*}{3} & Pendidikan Terakhir & & \\
\hline & $\Leftrightarrow \mathrm{SD}$ & 5 & 5 \\
\hline & SMP/MTS & 32 & 32 \\
\hline & SMA/MA & 50 & 50 \\
\hline & Sarjana & 13 & 13 \\
\hline & Lainnya & 0 & 0 \\
\hline \multirow{5}{*}{4} & Jumlah Keluarga & & \\
\hline & Satu orang & 3 & 3 \\
\hline & Dua orang & 15 & 15 \\
\hline & Tiga orang & 46 & 46 \\
\hline & Lebih dari tiga orang & 36 & 36 \\
\hline \multirow{6}{*}{5} & Pendapatan Per Bulan & & \\
\hline & $\Leftrightarrow R p \quad 0-R p \quad 250.000,00$ & 1 & 1 \\
\hline & $\Leftrightarrow R p \quad 250.000,00-R p 1.000 .000,00$ & 37 & 37 \\
\hline & $\Leftrightarrow R p 1.000 .000,00-R p 2.000 .000,00$ & 27 & 27 \\
\hline & $\Leftrightarrow R p 2.000 .000,00-R p 3.500 .000,00$ & 26 & 26 \\
\hline & Lebih dari Rp $3.500 .000,00$ & 9 & 9 \\
\hline
\end{tabular}

Dilihat dari jenis kelamin responden $56,7 \%$ adalah laki-laki dengan jumlah 34 orang sisanya $43,3 \%$ atau sejumlah 26 adalah wanita. Hal ini terlihat sebaran responden hampir merata.

Jenis pekerjaan yang banyak dilakukan oleh responden adalah 36,7 \% adalah wiraswasta, $21,7 \%$ adalah berprofesi petani, $20 \%$ adalah profesi pegawai swasta, $11,7 \%$ proesinya sebagai PNS, $5 \%$ berprofesi sebagai Pegawai TNI/Polri dan pekerjaan lainnya ada $3 \%$. Hal ini menunjukkan bahwa sebagian besar responden adalah wiraswasta dan petani, sisanya pegawai baik dari swasta maupun negeri.

Sedangkan responden yang dilihat dari tingkat pendidikan $43,4 \%$ adalah tamatan SMU, 25\% adalah tamatan SMP sederajat, $23,3 \%$ adalah tamatan perguruan tinggi dan sisanya $8,3 \%$ adalah pendidikan tamat SD. Hal ini menunjukkan sebaran responden mencerminkan sebagian besar berpendidikan menengah keatas.

Responden dengan jumlah keluarga 3 (tiga) orang merupakan proporsi yang terbesar sebanyak 43,3\%, kemudian dengan jumlah keluarga 2 orang 26,7\%,keluarga yang lebih 3 Orang 20\%dan sisanya yang jumlah keluarganya 1 orang hanya 10\%. Hal ini mencerminkan responden dalam kehidupan rumah tangganya dalam kondisi menanggung biaya hidup yang masih wajar. 
Sedangkan bila diukur dari pendapatan responden yang berpenghasilan 1 juta - 2 juta sebanyak 38,3\%, kemudian 2 juta lebih - 3,5 juta sebanyak $25 \%$, berpenghasilan250rb - 1 juta sebanyak $20 \%$, dan lebih dari 3,5 juta per bulan sebanyak15\%. Sedangkan yang kurang dari 250rb sebanyak 1,7\%. Hal ini menunjukkan rata-rata penghasilan mereka sudah representatif mencukupi.

b. Analisa Diskriptif

Analisis deskriptif dimaksudkan untuk mengetahui jawaban responden yang terendah dan tertinggi, serta kecenderungan responden yang dilihat melalui rata-rata keseluruhan dengan standar deviasi dari variabel Minat Masyarakat Terhadap BPR, Tingkat Persaingan Lembaga Keuangan Bank Dan Lembaga Keuangan Bukan Bank, Potensi Tabungan dan Deposito BPR Baru, Potensi Kredit BPR Baru dan Target Pasar Penyaluran Kredit dan Penghimpunan Dana. Hasil analisis deskriptif disajikan dalam Tabel 4.

Tabel 4. Hasil Analisis Deskripsi

\begin{tabular}{|l|c|c|c|c|}
\hline \multicolumn{1}{|c|}{ Variabel yang diteliti } & Minimum & Maksimum & Rata-Rata & $\begin{array}{c}\text { Simpangan } \\
\text { Baku }\end{array}$ \\
\hline Minat Masyarakat Terhadap BPR & 1 & 5 & 4.43 & 0.76 \\
\hline $\begin{array}{l}\text { Tingkat Persaingan Lembaga } \\
\text { Keuangan Bank Dan Lembaga } \\
\text { Keuangan Bukan Bank }\end{array}$ & 1 & 5 & 4.28 & 0.81 \\
\hline $\begin{array}{l}\text { Potensi Tabungan dan Deposito } \\
\text { BPR Baru }\end{array}$ & 1 & 5 & 4.55 & 0.76 \\
\hline $\begin{array}{l}\text { Potensi Kredit BPR Baru } \\
\begin{array}{l}\text { Target Pasar Penyaluran Kredit } \\
\text { dan Penghimpunan Dana }\end{array}\end{array}$ & 1 & 5 & 4.17 & 0.78 \\
\hline
\end{tabular}

Berdasarkan tabel 4. di atas diketahui bahwa Minat Masyarakat Terhadap BPR nilai terendah adalah sebesar 1 , dan skor yang tertinggi adalah sebesar 5 . Hal ini berarti bahwa ada responden tidak berminat terhadap BPR dan ada responden yang berminat terhadap BPR. Hasil rata-rata persepsi responden terhadap minat masyarakat terhadap BPR sebesar 4.43 dengan penyimpangan data sebesar 0.76 . Hal ini berarti sebagian responden membeikan persepsi berminat terhadap adanya BPR. Hal ini mencerminkan minat masyarakat sangat positif terhadap keberadaan BPR.

Kemudian berdasarkan tabel di atas diketahui bahwa variabel Tingkat Persaingan Lembaga Keuangan Bank Dan Lembaga Keuangan Bukan Bank nilai terendah adalah sebesar 1, dan skor yang tertinggi adalah sebesar 5 . Hal ini berarti bahwa ada responden memberikan respon tidak setuju kepada tingkat persaingan BPR dan ada responden yang memberikan respon sangat setuju dengan tingkat persaingan BPR. Hasil rata-rata persepsi responden terhadap Tingkat Persaingan Lembaga Keuangan Bank Dan Lembaga Keuangan Bukan Bank sebesar 4.28 dengan penyimpangan data sebesar 0.81. Hal ini berarti sebagian responden membeikan persepsi baik terhadap adanya persaingan BPR. Hal ini mencerminkan pemahaman masyarakat sangat positif terhadap persaingan di BPR.

Selanjutnya Berdasarkan tabel di atas diketahui bahwa persepsi terhadap Potensi Tabungan dan Deposito BPR Baru nilai terendah adalah sebesar 1, dan skor yang tertinggi adalah sebesar 5. Hal ini berarti bahwa ada responden tidak berminat terhadap Potensi Tabungan dan Deposito BPR Baru dan ada responden yang berminat terhadap 
Potensi Tabungan dan Deposito BPR Baru. Hasil rata-rata persepsi responden terhadap Potensi Tabungan dan Deposito BPR Baru sebesar 4.55 dengan penyimpangan data sebesar 0.76 . Hal ini berarti sebagian responden membeikan persepsi berminat terhadap Potensi Tabungan dan Deposito BPR Baru. Hal ini mencerminkan minat masyarakat sangat positif terhadap Potensi Tabungan dan Deposito BPR Baru.

Kemudian Berdasarkan tabel di atas diketahui bahwa persepsi terhadap Potensi Kredit BPR Baru nilai terendah adalah sebesar 1, dan skor yang tertinggi adalah sebesar 5. Hal ini berarti bahwa ada responden tidak berminat terhadap Potensi Kredit BPR Baru dan ada responden yang berminat terhadap Potensi Kredit BPR Baru. Hasil rata-rata persepsi responden terhadap minat masyarakat terhadap Potensi Kredit BPR Baru sebesar 4.17 dengan penyimpangan data sebesar 0.78 . Hal ini berarti sebagian responden membeikan persepsi berminat terhadap Potensi Kredit BPR Baru. Hal ini mencerminkan minat masyarakat sangat positif terhadap Potensi Kredit BPR Baru.

Hasil rata-rata persepsi responden terhadap minat masyarakat terhadap Target Pasar Penyaluran Kredit dan Penghimpunan sebesar 4.47 dengan penyimpangan data sebesar 0.73 . Hal ini berarti sebagian responden membeikan persepsi berminat terhadap Target Pasar Penyaluran Kredit dan Penghimpunan. Hal ini mencerminkan minat masyarakat sangat positif terhadap Target Pasar Penyaluran Kredit dan Penghimpunan

\section{Implikasi Hasil Penelitian}

\section{Minat Masyarakat Terhadap BPR}

Dari penelitian pasar yang telah dilakukan untuk minat masyarakat terhadap BPR yang diukur dari keberadaan BPR yang beroperasi di wilayah Banyuwangi, maka pelayanan yang diberikan, profesionalitas layanan, menawarkan produk yang menarik serta kemudahan dalam akses pelayanan perbankan dapat disimpulkan bahwa minat masyarakat merespons sangat positif terhadap keberadaan BPR di wilayah Banyuwangi. Sehingga masyarakat akan menerima bila ada aktivitas perbankan di daerah tersebut untuk memberikan pelayanan perbankan.

Dalam realitasnya keberadaan BPR yang mampu memberikan brand tersendiri bagi masyarakat pengguna, apalagi pelayanan yang diberikan selalu diorientasikan kepada kepuasan nasabah. Pelayanan yang diberikan memberikan warna tersendiri yang diukur dari keramahan, sopan santun, kecepatan dan rasa puas oleh masyarakat pengguna. Produk yang ditawarkan memberikan warna yang berbeda dibanding dengan produk pesaing lainnya, sehingga produk tersebut dinilai bisa memberikan kemudahan serta memberian benefit bagi masyarakat pengguna.

2. Tingkat Persaingan LKB dan LKNB pada Target Pasar

Respon masyarakat terhadap tingkat persaingan LKB dan LKNB pada target pasar yang diukur dari kemampuan bersaing dengan lembaga BPR lainnya, kemampuan bersaing dengan lembaga non BPR, keunggulan yang dimiliki, daya tarik produk serta suku bunga yang kompetitif, sebagian besar masyarakat merespon positif sehingga hal ini berarti sebagian besar responden memberikan persepsi baik terhadap adanya persaingan BPR serta mencerminkan pemahaman masyarakat sangat positif terhadap persaingan di BPR. 
Dalam implementasinya BPR mampu memberikan nilai-nilai unggul yang mereka miliki, terutama dukungan dana pihak ketiga, regulasi implementasi di lapangan, dukungan moral yang kuat dari pemerintah daerah. Sehingga BPR yang baru nanti harus mampu memberikan tingkat rate yang kompetitif dibanding para pesaing. Sehingga dukungan yang kuat tersebut bisa memberikan kemudahan dalam implementasi kegiatan perbankannya.

\section{Potensi Tabungan dan Deposito BPR Baru}

Potensi tabungan dan deposito BPR baru yang diukur dari produk tabungan dan deposito lebih kompetitif, peluang dana lebih, pemberian hadiah yang menarik, bunga yang ditawarkan serta jaminan LPS. Maka sebagian responden memberikan persepsi baik dan berminat terhadap Potensi Tabungan dan Deposito BPR Baru. Hal ini mencerminkan minat masyarakat sangat positif terhadap Potensi Tabungan dan Deposito BPR Baru.

Dengan potensi keunggulan produk yang diberikan kepada masyarakat memberikan daya tarik tersendiri sehingga banyak masyarakat pengguna yang menggunakan jasa perbankan di BPR wilayah Banyuwangi, sehingga potensi tabungan dan deposito semakin berkembang dan bergairah. Ditambah dengan strategi marketing yang handal dan mengena. Ini yang menyebabkan banyak pendapat positif dari pengguna jasa perbankan terhadap BPR yang akan beroperasi di Banyuwangi

\section{Potensi Kredit BPR Baru}

Sedangkan potensi Kredit BPR Baru yang diukur dari produk lebih kompetitif, kekuarangan dana, ada kemudahan dalam pengajuan kredit, bunga kredit yang menarik serta sebagian responden membeikan persepsi berminat terhadap Potensi Kredit BPR Baru. Hal ini mencerminkan minat masyarakat sangat positif terhadap Potensi Kredit BPR Baru.

Kelebihan yang dimiliki di sektor rate yang kompetitif dan tata cara pengajuan kredit yang simple dan tidak berbelit-belit dengan tetap mengacu keoada SOP kredit, memberikan daya tarik bagi masyarakat pengguna atas kelebihan yang dimiliki BPR baru nantinya. Sehingga banyak masyarakat pengguna yang memilih untuk mendapatkan jasa perbankan terkait dengan penganjuan kredit. Hal inilah cerminan kekuatan potensi kredit yang nantinya akan bisa dikembangkan secara proporsional.

5. Keberadaan Target Pasar Penyaluran Kredit dan Pengimpunan Dana

Untuk keberadaan target pasar penyaluran kredit dan pengimpunan yang diukur dari kehadiran BPR, keunggulan yang dimiliki, profesional dan dipercaya, selalu membantu masyarakat dan berkinerja baik dan profesional sebagaian masyarakat memberikan nilai positif serta mencerminkan minat masyarakat sangat positif terhadap Target Pasar Penyaluran Kredit dan Penghimpunan.

Dengan potensi kekuatan dan peluang yang besar pada BPR yang akan beroperasi nantinya, dalam mengembangkan potensi perbankaannya akan mampu dicapai apalagi persepsi masyarakat yang mendukung persepsi keunggulan yang dimiliki oleh BPR baru. Kepedulian BPR baru di dalam berbagai aktivitas sosial yang dilaksanakan memberikan keyakinan tersendiri bagi masyarakat pengguna untuk lebih nyaman dan percaya dalam memenuhi kebutuhan pelayanan perbankan yang diharapkan dari masyarakat pengguna di kabupaten Banyuwangi. 


\section{Kesimpulan}

Dari penelitian pasar yang telah dilakukan untuk minat masyarakat terhadap BPR yang diukur dari keberadaan BPR di Banyuwangi, pelayanan yang diberikan, profesionalitas layanan, menawarkan produk yang menarik serta kemudahan dalam akses pelayanan perbankan dapat disimpulkan bahwa minat masyarakat merespons sangat positif terhadap keberadaan PT BPR Artha Waringin Situbondo. Sehingga masyarakat akan menerima bila ada aktivitas perbankan di daerah tersebut untuk memberikan pelayanan perbankan.

\section{Daftar Pustaka}

Alhusna, Galuh Gumelar,(2011), Analisis kelayakan usaha kedai kopi mobile di wilayah Kota Bogor, Bogor: Central Library of Bogor Agricultural University.

Roefliana, Insani, (2007). Analisis Kelayakan Finansial Produk Madu Dalam Kemasan Sachet (Studi Kasus Industri Kecil Madu Mutiara Tugu Ibu, Depok),Bogor: Central Library of Bogor Agricultural University.

Syarif, Kasman \& Dewi, Farida Ratna (2011), Analisis Kelayakan Usaha Produk Minyak Aromatik Merek Flosh (Studi Kasus Di UKM Marun Aromaterapi), Bogor: Central Library of Bogor Agricultural University.

Kasmir, (2012). Studi Kelayakan Bisnis. Jakarta: .Prenada Media

Suliyanto. (2010). STUDI KELAYAKAN BISNIS pendekatan praktis,Yogyakarta: Andi Offset

Wylma, L. (2008). Analisis Kelayakan Bisnis Restoran Sushi di kelapa Gading Jakarta. Jakarta: Perpustakaan Universitas Indonesia. 